PART 3

Human Rights and Large-Scale Land Acquisitions 
Christophe Golay - 9789004304758

Downloaded from Brill.come4/26/2023 10:17:16AM via free access 


\title{
Identifying and Monitoring Human Rights Violations Associated with Large-Scale Land Acquisitions

\author{
A Focus on United Nations Mechanisms and South-East Asia
}

Christophe Golay

\begin{abstract}
This chapter aims to contribute to the debate on contemporary 'land grabbing' and its impact on human rights. It describes the role played by United Nations (UN) human rights mechanisms in monitoring violations associated with large-scale land acquisitions (LSLAS), with a focus on UN treaty bodies. A typology of human rights violations associated with LSLAs is presented, on the basis of the assessment that UN treaty bodies have made in examining the impact of LSLAs in Cambodia, Indonesia, Laos, and Vietnam. Three common threads can be extracted from this assessment. The first relates to the actual or potential human rights implications of the internal displacement and forced evictions caused by LSLAs, which often lead to drastic changes in livelihood opportunities. The second involves the impact of LSLAs on the procedural rights of indigenous peoples, in particular their right to free, prior, and informed consent to policies and activities that directly affect their land, territory and livelihoods. The third concerns the disproportionately negative effect that LSLAs have on individuals and groups who are vulnerable to discrimination and marginalisation, including women, children, indigenous peoples, rural communities, and small-scale farmers. The example of Laos, where we conducted research in 2012 and 2013, confirms the assessment made by UN treaty bodies. The overall conclusion is that human rights are well recognised in international law and that national laws seem to be adequate in many countries, including
\end{abstract}

The author was joint coordinator of the Swiss Network for International Studies (sNIs)funded project "Large-Scale Land Acquisitions in Southeast Asia: Rural Transformations between Global Agendas and Peoples' Right to Food". He would like to thank Irene Biglino for her contribution to this chapter, and for her invaluable support in the research that led to the writing of this contribution. Ioana Cismas, Patricia Paramita and Samuel Segura Cobos should also be thanked for previous research done on the subject in the context of the SNISfunded project (www.snis.ch).

(C) Graduate Institute of International and Development Studies, 2016 | DOI 10.1163/9789004304758_010 This is an open access chapter distributed under the terms of the Creative Commons Attribution-

Noncommercial 3.o Unported (CC-BY-NC 3.0) License. 
in South-East Asia. Yet, human rights instruments and national laws are poorly implemented on the ground, or not implemented in favour of local communities.

\section{Introduction}

The aim of this article is to contribute to the debate on contemporary 'landgrabbing' and its impact on human rights (Cotula, 2009; De Schutter, 2011a; De Schutter, 2011b; Monsalve Suárez, 2013; Cotula, 2012; Narula, 2013; Künnemann and Monsalve Suárez, 2013; Clays and Vanloqueren, 2013; Golay and Biglino, 2013) and, more specifically, to present a typology of human rights violations associated with large-scale land acquisitions (LSLAs) and present the role played by United Nations (UN) mechanisms in monitoring these violations.

The focus in this contribution will be on UN monitoring mechanisms, which can be classified as political or quasi-judicial (Golay, 2009), and not on access to justice, despite the fact that a key principle of human rights law is that victims of human rights violations should have access to justice (Borghi and Postigione Blommestein, 2006, IX). Access to justice has also been described as a powerful tool for giving meaning to human rights 'in small places close to home' (Robinson, 2003, 1). For the UN Committee on Economic, Social and Cultural Rights (CESCR), ' '[a]ny person or group who is a victim of a violation of [a human right] should have access to effective judicial or other appropriate remedies at both national and international levels. All victims of such violations are entitled to adequate reparation, which may take the form of restitution, compensation, satisfaction or guarantees of non repetition' (1999, 32).

As we will see with the example of Laos, access to justice for victims of human rights violations is often very difficult in practice (Special Rapporteur on Extreme Poverty, 2012). And in the great majority of cases, mechanisms that monitor human rights violations associated with LSLAs are not judges, but administrations at the local and national levels and UN human rights monitoring bodies and experts at the international level. This contribution will focus on the second category, with an emphasis on their role in monitoring human rights violations in South-East Asia.

The second part of this chapter presents the international legal basis that can be used to monitor human rights violations associated with LSLAs. The third part focuses on the role played by UN treaty bodies in monitoring human rights violations in Cambodia, Laos, Indonesia, and Vietnam, and presents a

1 The Committee on Economic, Social and Cultural Rights (CESCR) oversees compliance with the International Covenant on Economic, Social and Cultural Rights (ICESCR). 
typology of human rights violations associated with LSLAs. The fourth part takes the example of Laos as a case study.

\section{International Legal Basis for Monitoring Human Rights Violations} Associated with LSLAS

International human rights law includes a number of treaties and soft-law instruments. With regard to the first category, treaties relevant to monitoring the impact of LSLAs include the International Covenant on Civil and Political Rights (ICCPR), the International Covenant on Economic, Social and Cultural Rights (ICESCR), the International Convention on the Elimination of All Forms of Racial Discrimination (ICERD), the Convention on the Elimination of All Forms of Discrimination against Women (CEDAW), the Convention on the Rights of the Child (CRC) and the Convention on the Rights of Persons with Disabilities (CRPD).

Under these treaties, state parties have the obligation to respect, protect and fulfil human rights in the context of LSLAs, without any discrimination (Special Rapporteur on the Right to Food, 2009). They should also implement policies to support particularly vulnerable individuals and groups, such as women and indigenous peoples. Women's rights to land and property are specifically protected in the CEDAW Convention (Arts. 14(2) and 16), and the rights of indigenous peoples in the UN Declaration on the Rights of Indigenous Peoples and in the International Labour Organization (ILO) Convention No. 169 concerning Indigenous and Tribal Peoples. Indigenous peoples' rights of ownership, possession and control of their land, territories and resources, and states' obligations to guarantee their effective protection, as well as the requirement of indigenous peoples' prior, free, and informed consent-all recognised in international law-are particularly important in the context of LSLAs.

If we except ILO Convention No. 169, these international treaties have been accepted by all or a great majority of states, and therefore potentially offer a good basis for UN bodies to monitor human rights violations associated with LSLAS.

Turning to soft law, it must be highlighted that in recent years a number of instruments have been developed with a view to reaffirming the relevance of human rights in the context of LSLAS (UN Special Rapporteur on the Right to Food, 2009; Golay and Biglino, 2013). The most important step in this area was the adoption, by the UN Committee on World Food Security, of Voluntary Guidelines on the Responsible Governance of Tenure of Land, Fisheries and Forests in the Context of National Food Security (Governance 
of Tenure Guidelines) in May 2012. The main objective of the Governance of Tenure Guidelines is to promote secure tenure rights and equitable access to land, fisheries and forests in order to reduce poverty and realise the right to food. Two central elements of the guidelines are the need to identify, record and respect legitimate tenure rights, whether formally recorded or not, and to protect tenure rights holders against forced evictions (guidelines 3.1.1. and 3.1.2, respectively). Special protection should be accorded to smallholders and to indigenous peoples and other communities with customary tenure systems (guideline 7.3). The guidelines also recommend that states provide safeguards to protect legitimate tenure rights, human rights, livelihoods, food security and the environment from risks that could arise from LSLAs (guideline 12.6) and that responsible investments should do no harm, safeguard against dispossession of legitimate tenure right holders and environmental damage, and respect human rights (guideline 12.4). The guidelines further underline that redistributive reforms can facilitate broad and equitable access to land and inclusive rural development (guideline 15.1).

In March 2010, the UN Special Rapporteur on the right to food, Olivier De Schutter, ${ }^{2}$ submitted a report to the Human Rights Council in which he described the phenomenon of LSLAS and its causes and presented a set of 11 human rights principles applicable to LSLAs (Special Rapporteur on the Right to Food, 2009). ${ }^{3}$ The report's objective was to delineate the 'minimum human rights obligations' that states, but also investors and financial institutions, must comply with when negotiating and concluding LSLAs. For De Schutter, the principles 'are not optional; [but] follow from existing international human rights norms' (Special Rapporteur on the Right to Food, 2009, 5).

The 11 principles describe the obligation of states and investors to conduct negotiations leading to LSLAs in a fully transparent manner and with the participation of local communities; the requirement of free, prior, and informed consent of the local communities concerned; the general prohibition of forced evictions; the obligation to recognise and protect the land tenure rights of local communities; the importance of the sharing of revenues generated by LSLAS

2 Olivier De Schutter's mandate began in May 2008 and ended in May 2014. Jean Ziegler was the first mandate holder between September 2000 and April 2008. Hilal Elver replaced Olivier De Schutter in June 2014.

3 Among the many other UN Special Rapporteurs who could have played a role in response to LSLAs (Piccone, 2012; Subedi et al., 2011; Golay et al., 2011; Nifosi, 2005), the UN Special Rapporteur on human rights in Cambodia offered the most important response in monitoring the impact of LSLAs in this country in 2012. See Golay and Biglino, 2013, 1637-1638; and Cismas and Paramita in this volume. 
with the local population; the necessity of choosing labour-intensive farming systems in countries facing high levels of rural poverty and few employment opportunities in other sectors; the need to protect the environment; the necessity of including clear and detailed obligations for investors in the agreements, with sanctions for non-compliance; the need to include a clause providing that a certain minimum percentage of the crops produced will be sold in local markets in food-importing countries, to contribute to local food security; the necessity to undertake prior impact assessments, including on food security, the environment and employment; the obligation to protect indigenous peoples' rights; and the obligation to respect the applicable ILO instruments (Special Rapporteur on the Right to Food, 2009, 5).

De Schutter's principles were not received unopposed and attracted some criticism from certain states and civil society organisations, which feared that they would 'legitimise' land grabbing, instead of contributing to halting the phenomenon (Clays and Vanloqueren, 2013). But De Schutter's principles have also been used to assess the implications of LSLAs in concrete cases. ${ }^{4}$

\section{Identifying and Monitoring Human Rights Violations Associated with LSLAs in South-East Asia: the Role Played by United Nations Treaty Bodies}

Several UN mechanisms have monitored human rights violations associated with LSLAs (Golay and Biglino, 2013). This section focuses on UN treaty bodies, with particular emphasis on the monitoring role they have played in relation to South-East Asian countries. ${ }^{5}$

The UN treaty bodies are committees made up of independent experts, established under the international human rights treaties, which monitor the implementation of the treaties through the periodic review of reports submitted by state parties (Vandehole, 2004; Bassiouni and Schabas, 2011; Keller and

4 For example, in 2010 the Government of Switzerland participated in a public symposium, alongside the Director of Addax Bioenergy, a Geneva-based company investing in Sierra Leone, and civil society organisations representing communities affected by the LSLA in Sierra Leone. During the event, the human rights impact of Addax's LSLA was discussed with reference to De Schutter's principles. The symposium Business and human rights. Clearing the path to foster corporate accountability took place on 18 October 2010 in Geneva. More information is available at http://www.reports-and-materials.org/Land-grabbing-symposiumGeneva-18-Oct-2010.pdf (accessed on 27 April 2015).

5 This second part is largely inspired by Golay and Biglino (2013, 1635-1642), but the focus here is on South-East Asia. 
Ulfstein, 2012). Most of them also have the competence to receive individual or collective complaints-also called 'communications' - in cases of human rights violations (Golay, 2009, 32-33).

Many UN treaty bodies have monitored human rights violations associated with LSLAS in the context of the periodic review of reports submitted by state parties; these include the CESCR, the Committee on the Elimination of Racial Discrimination (CERD), the Committee on the Elimination of Discrimination against Women (CEDAW Committee), and the Committee on the Rights of the Child (CRC Committee). Based on a review of their examination of state parties' reports since 2006, at least three common threads can be extracted from their monitoring and recommendations.

The first overarching concern relates to the actual or potential human rights implications of internal displacement and forced evictions caused by LSLAS, which often lead to drastic changes in livelihood opportunities. A connected concern is that in many cases the displaced groups are not resettled and compensated for their livelihood losses. In its consideration of Cambodia, the CESCR examined issues relating to the human rights impact of LSLAS in quite some detail (see also Cismas and Paramita in this volume), and concluded that, 'authorities of the [state] party are actively involved in land-grabbing' (CESCR, 2009, 30). The CESCR expressed grave concerns over the vast concessions granted to private companies and noted the increase in forced evictions and threats of eviction linked to such concessions and expressed deep concern about the lack of effective consultation with persons affected by the forced evictions. It also called attention to the inadequate compensation or relocation provisions for families forcibly removed from their properties (CESCR, 2009, 30).

The second common thread involves the impact of LSLAs on the procedural rights of indigenous peoples, and in particular the fact that policies and activities that directly affect their land, territory and livelihoods require their free, prior, and informed consent. For example, the CESCR examined the impact of land concessions on indigenous peoples during its assessments of Cambodia. In its recommendations, the committee highlighted the need for carrying out environmental and social impact assessments and consultations with affected communities with regard to economic activities, including mining and oil explorations, 'with a view to ensuring that these activities do not deprive the indigenous peoples to the full enjoyment of their rights to their ancestral lands and natural resources' $(2009,16)$. In further pointing out that legislation providing for the titling of indigenous communities' lands had not been implemented in an effective manner, the CESCR urged Cambodia to provide for the implementation of the provisions without delay. 
The CERD has also extensively monitored the impact of LSLAs on the rights of indigenous peoples. In 2007, for instance, it expressed concerns about the denial of indigenous peoples' rights in Indonesia in connection with LSLAS made for agro-industrial purposes, such as the expansion of oil palm plantations on indigenous territories $(2007,17)$. The committee called on Indonesia to secure indigenous peoples' ownership rights to their lands, territories and resources and to obtain their consent prior to further oil palm development. The CERD voiced similar concerns in 2012 in its review of Vietnam (2012b, 15).

In examining the situation in Cambodia, the CERD noted that such transactions were in many cases being conducted 'to the detriment of particularly vulnerable communities such as indigenous peoples' $(2010,16)$. Another concern related to reports that concessions affecting land traditionally occupied by indigenous peoples were being granted without full consideration, or the exhaustion of procedures provided for by national legislation. The committee strongly encouraged the development of a series of protective measures, such as procedures to delay the issuing of concessions on indigenous lands and only issue such concessions pursuant to free, prior, informed consent being given by the affected communities. The reach of the committee's recommendations extended even further, as it called on business entities negotiating concessions to take into consideration their corporate social responsibility as it relates to the rights and well-being of local populations (CERD, 2010, 16).

The third recurrent theme is the disproportionately negative effect that LSLAs have on other populations that are vulnerable to discrimination and marginalisation. In addition to indigenous peoples, concerns have been raised about negative impacts on women, children, rural communities, and smallscale farmers. CEDAW focused its attention on female heads of households in Cambodia who had lost their sources of livelihood because of the confiscation of land by private companies and were excluded from decision-making processes concerning land distribution (2006, 31). Similarly, in its concluding observations on Cambodia in June 2011, the CRC expressed a deep concern that thousands of children and families, especially the urban poor, small-scale farmers and indigenous communities, were continuing to be deprived of their land 'as a result of land grabbing and forced evictions carried out by people in positions of power' (2011, 61). The committee recommended the establishment of a 'national moratorium on evictions until the determination of the legality of land claims is made' (CRC, 2011, 61). As an overarching recommendation in its assessment of Cambodia, the CERD requested that a proper balance be struck between development objectives and the rights of citizens and that the former not be enacted at the expense of the rights of vulnerable persons and groups covered by the Convention [on the Elimination of All Forms of Racial 
Discrimination]' (2010, 16). Following CEDAW's review of Laos, it was recommended by the committee that the state party ensure that development projects are implemented only after gender impact assessments involving rural women have been conducted (2009, 44-45).

Finally, a separate issue relates to land policy reforms financed and promoted through development cooperation and assistance, which in certain cases have been found to lead to human rights violations (Künnemann and Monsalve Suárez, 2013, 127). One of these cases came to the CESCR's attention: the involvement of the German Agency for International Cooperation in financing the land titling system in Cambodia. It has been suggested that the scheme-aimed at recognising individual and not collective rights-contributed to weakening the tenure status of vulnerable and marginalised communities, exposing them to the risk of eviction as a result of LSLAS (Künnemann and Monsalve Suárez, 2013). Following that reasoning in its review of Germany in 2011, the CESCR explicitly cited the land-titling scheme in Cambodia to illustrate the concern that 'the [state] party's development cooperation programme has supported projects that have reportedly resulted in the violation of economic, social and cultural rights' (2011, 11).

An overview of UN treaty bodies' monitoring function must also briefly consider communication procedures. A number of international human rights treaties are supplemented by Optional Protocols allowing for the consideration of individual or collective complaints usually referred to as 'communications'. Avenues that are potentially relevant for monitoring human rights violations associated with LSLAs are those established by the Optional Protocol to the ICCPR, by Article 14 of the ICERD, and by the Optional Protocol to the CEDAW that has been ratified by Cambodia, the Philippines, and Thailand (Golay, 2009,

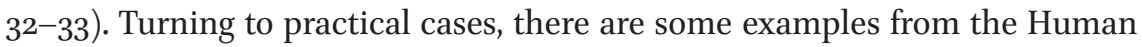
Rights Committee, the body entrusted with monitoring the ICCPR, in which indigenous communities have sought protection of their way of life, their economic activities and their means of subsistence (Human Rights Committee, 2000 and 2009; Golay and Özden, 2009, 55). These cases, although not dealing necessarily with LSLAS and cases in South-East Asia, provide some useful lessons on how these UN mechanisms may be used in the future to monitor the actual or potential human rights violations associated with LSLAs in SouthEast Asian countries.

A communication procedure that has recently become available is the one established by the Optional Protocol to the ICESCR (Biglino and Golay, 2013). The optional protocol, which entered into force on 5 May 2013, provides for the right of individuals and groups to submit complaints regarding violations of the rights contained in the covenant. This makes this procedure ideally suited 
to victims of human rights violations associated with LSLAs who wish to submit communications to the CESCR, but no South-East Asian country has yet accepted it.

\section{4}

The Example of Laos

We undertook field research with colleagues in Laos in 2012 and 2013 in the context of a research project on the impact of LSLAs on the right to food in South-East Asia. ${ }^{6}$ The presentation of Laos as a case study in this part of the chapter complements information and cases analysed in other chapters of this volume, in relation to Laos and Cambodia (see Messerli et al., Gironde and Senties Portilla, and Cismas and Paramita in this volume). This part begins with a presentation of the relevant legal framework in Laos, followed by an analysis of the examination of human rights violations associated with LSLAS in Laos by UN treaty bodies.

\subsection{Legal Framework and Lack of Access to Justice and Effective Remedies at the National and Regional Levels}

In Laos, like in Cambodia (see Cismas and Paramita in this volume) and several other countries, there is a solid legal framework that, in principle, offers numerous safeguards in human rights terms. However, there is an important gap between what constitutes 'law on paper' and how that law is actually implemented and applied 'on the ground'.

Laos has ratified the most important international human rights treaties, including the ICCPR, ICESCR, ICERD, CEDAW, CRC, and CRPD. But it has not ratified optional protocols allowing for individual or collective communications in cases of human rights violations.

The Constitution of Laos (adopted in 2003) recognises a list of fundamental rights, including the right to education (article 38 ), the right to health (article 39), the right to submit complaints and petitions (article 41), and the rights and freedoms of expression, assembly, and association (article 44). It also provides that the " $[\mathrm{s}]$ tate, society and families attend to implementing development policies and supporting the progress of women and to protecting legitimate rights and benefits of women and children' (article 29). It is worth mentioning however that many human rights are not enshrined in the

6 For a description of the two-year research project and to access the outputs that were produced by the researchers, visit http://www.snis.ch/project_large-scale-land-acquisitionssoutheast-asia-rural-transformations-between-global-agendas. 
Constitution, such as the right to life, the right to food, and the right to housing, and that the Constitution does not mention international human rights instruments ratified by Laos. It is also important to note that Laos's legal framework does not recognise indigenous peoples but ethnic groups (articles 8 and 22).

The most important national law in the context of LSLAS is the 2003 Land Law, which creates eight land categories: agricultural land, forestland, water area land, industrial land, communication land, cultural land, land for national defence and security, and construction land. When it was adopted, one of its main objectives was to support small-scale farmers in better using agricultural land, and to provide them with a secure legal environment. However, more than ten years after its adoption, the great majority of people living in Laos' rural areas remain untouched by or unaware of these potential benefits (Gironde et al., 2014, 40). Senties Portilla found that, in practice, the Land Law 'paved the way for foreign investment in land through [... ] legally defining the circumstances under which land can be conceded to investors [, with] enormous implications [for] the typically rural and subsistence-oriented agrarian structures of the country, which [...] largely remain founded on customary practices' (2012, 61-62, 69). She also observed that the titling of communal lands that could be used to protect villagers against restrictions imposed by corporations, for example to accessing food and water, is poorly implemented (2012, 67-69).

What also emerges with great clarity in Laos is that access to justice and effective remedies in cases of human rights violations is extremely difficult, or non-existent. Individuals affected by LSLAs encounter many hurdles in their attempts to access justice (Gironde et al., 2014, 47). In a report presented to the UN General Assembly in 2012, the UN Special Rapporteur on extreme poverty and human rights Magdalena Sepulveda Carmona developed an analytical structure for the analysis of the obstacles, experienced when attempting to access justice, faced by people living in poverty. The special rapporteur's framework identifies a set of macro-categories whereby obstacles can be classified (Special Rapporteur on Extreme Poverty, 2012). A large number of issues identified in the framework reflect barriers that exist to accessing justice in Laos, including 'institutional and structural' as well as 'social and cultural' obstacles.

Access to other kind of remedies, including those of an administrative nature, is also extremely difficult in Laos for victims of human rights violations associated with LSLAs (Gironde et al., 2014, 47). The main avenue that exists is a hotline, created in 2012, to the national assembly. According to many, a great number of complaints submitted through this hotline were related to 
land disputes (Baird, 2011). In one case at least, it allegedly led to a member of the national assembly visiting the community and compensation being given to its members (Gironde et al., 2014, 47). But as the process is purely oral it is difficult to gather more information regarding the efficiency of this remedy.

This lack of access to justice and effective remedies in Laos is representative of a context in which human rights education is extremely poor, or non-existent, and speaking about and reporting human rights violations is extremely difficult. Illustrative of this context is the fact that two people who spoke out on human rights issues were either forced to leave the country or disappeared. On 9 December 2012, the country director of Helvetas, a Swiss non-governmental organisation (NGO) working in the field of development and with rural communities in Laos, Anne-Sophie Gindroz, was given 48 hours to leave the country because she criticised the government for creating a difficult environment for development actors and civil society organisations by restricting freedoms of expression and association (Radio Free Asia, 2012). ${ }^{7}$ One week later, on 15 December 2012, Sombath Somphone, a well-known Lao activist, disappeared. More than two years later, the government of Laos still stands accused of not conducting a proper investigation into Somphone's disappearance, and his family has no information on where he could be (APHR, 2014). ${ }^{8}$ It also seems that there is no hope of a rapid improvement of the human rights situation in Laos, with new laws being proposed to Parliament to further restrict the freedoms of association and expression of NGOs and their members (APHR, 2014).

Unlike Africa, the Americas, and Europe, Asia is a region in which there is no regional human rights treaty, human rights court, or commission covering the region in its entirety (Golay, 2009, 37-46). When victims of human rights violations face difficulties accessing justice and effective remedies at the national

7 In a letter addressed in November 2012 to participants at a round table on foreign aid strategy in Laos, A.-S. Gindroz wrote: 'We are working in a challenging environment: this is a country governed by a single-party regime, where there is little space for meaningful democratic debate, and when taking advantage of that limited space, repercussions follow.' (Radio Free Asia, 2012). Before being evicted from the country, Ms. Gindroz chaired a coalition of civil society organisations working on land issues in Laos - the land issues working group (http:// www.laolandissues.org ) (accessed on 28 April 2015).

8 After a visit to Laos in September 2014, C. Santiago, Malaysian parliamentarian and vicepresident of the Association of Southeast Asian Nations (ASEAN) Parliamentarians for Human Rights (APHR) declared: 'The Lao authorities have erected a brick wall of silence on this investigation, so much so that the only intelligent conclusion is that there is in fact no investigation taking place at all and that the obstinacy is part of a cover up for state officials implicated in his abduction' (APHR, 2014). 
level, it is therefore impossible for them to use regional monitoring bodies. Two positive developments in this sphere were the establishment of the Association of Southeast Asian Nations (ASEAN) Intergovernmental Commission on Human Rights and the ASEAN Commission for the Promotion and Protection of the Rights of Women and Children, in 2009 and 2010, respectively. ${ }^{9}$ But the commissions' added value in the area of LSLAs and human rights remains unclear, as does their engagement with the topic (Gironde et al., 2014, 39).

\subsection{The Role Played by un Mechanisms in Monitoring Human Rights Violations Associated with LSLAs in Laos}

In a context in which access to justice and effective remedies is extremely difficult at the national and regional levels, national (Gender and Development Group-Alliance for Democracy in Laos) ${ }^{10}$ and international (IN DIGENous ${ }^{11}$ and UNPO $)^{12}$ NG O have used international treaties ratified by Laos to denounce the negative impacts of LSLAs. They have done so through the submission of parallel reports-parallel to the government report-when UN treaty bodies examined Laos's human rights record (Alliance for Democracy in Laos, 2012; INDIGENOUS, 2012; UNPO, 2012; GDG, 2008). These NGOs have targeted the CERD and the CEDAW committees, which have responded by evaluating human rights violations associated with LSLAs in Laos and issuing recommendations to the government (CERD, 2012a; CEDAW, 2009).

The CERD has examined the need to better protect the livelihoods - and the right to an adequate standard of living — of ethnic groups. In its consideration of reports concerning Laos, the committee reiterated the right of communities to give, or withhold, their free, prior, and informed consent and called for the state to ensure that this decision is respected in the planning and implementation of large-scale projects affecting these communities' lands and resources

9 In 2009 and 2010, these two institutions (composed of states' representatives) were created by ASEAN to monitor existing international human rights obligations of ASEAN members, in agreement with Article 14 of ASEAN's charter, adopted on 20 November 2007 and in force since 15 December 2008.

10 The Alliance for Democracy in Laos presents itself as a worldwide network of Lao political opposition organisations and active advocates committed to a peaceful change towards genuine democracy in Laos. It is an NGO and is based in Germany. Its website can be found at www.laoalliance.org (accessed on 28 April 2015).

11 Indigenous is the International Network for Diplomacy Indigenous Governance Engaging in Nonviolence Organizing for Understanding \& Self-Determination.

12 UNPO is the Unrepresented Nations and Peoples Organization, and is based in The Hague and Brussels. Its website can be found at www.unpo.org (accessed on 28 April 2015). 
(2012a, 16-17). Express references were made to the importance of 'the cultural aspect of land, as an integral part of the identity of some ethnic groups' (CERD 2012a, 16-17). Following its examination of the situation in Laos, the CEDAW committee recommended that the government ensure that development projects are implemented only after conducting gender-impact assessments involving rural women (2009, 44-45).

On the basis of the assessments made by un treaty bodies, and field research conducted in 2012 and 2013 in the context of a project on the human rights impact of LSLAs in South-East Asia, it is possible to conclude that the typology of human rights violations associated with LSLAs that we presented in the second part of this chapter (see part 2, above) is relevant when discussing human rights violations in Laos (Gironde et al., 2014, 43-46). As is the case in many other countries, such violations include the human rights implications of internal displacement and forced evictions caused by LSLAs, which often lead to drastic changes in livelihood opportunities, and in the great majority of cases leave the displaced individuals and communities without adequate resettlement and compensation for their losses in livelihood (see the cases in the province of Champasak described in the contribution by Gironde and Senties Portilla in this volume). They also include violations of ethnic minorities' right to give, or to withhold, their free, prior, and informed consent to externally imposed policies and activities that directly affect their livelihoods, and the disproportionately negative effect that LSLAs have on other individuals and groups who are vulnerable to discrimination and marginalisation, including women, children, rural communities, and small-scale farmers (Gironde et al., 2014, 43-46). Inadequate participation and consultation, and information asymmetry, also appear to constitute a dominant trend in Savannakhet and Luang Prabang provinces in Laos (Gironde et al., 2014, 45-46).

These violations also include the disproportionately negative effect that LSLAs have on individuals and groups who are vulnerable to discrimination and marginalisation. To give a concrete example, a study of the impacts of a land concession - of 7,00o ha, granted to a Chinese rubber company (Sino Company) in 2006 — on a local community in Nambak District, Luang Prabang Province in Laos, revealed that the implementation of the concession led to the large-scale enclosure of upland resources that these villages depended on (Friis, 2013). This also implied the imposition of a strict penalty scheme for damage to rubber trees caused by roaming animals, which led to a prohibition on villagers continuing to rear livestock, which had negative impacts on soil fertility and led to a decline in paddy rice yields. In a number of reported cases, individuals and their families were left with no option but to purchase food on 
the market although, due to their precarious economic conditions, they could not afford the rich, nutritious and diverse diet they had enjoyed when they had had agricultural land on which to grow food and access to forest areas that provided additional food sources (i.e. fish and wild animals) (Gironde et al., 2014, 45).

5 Conclusion

In the second and third parts of this contribution, we have presented the international legal basis that can be used to monitor human rights violations associated with LSLAS, and have provided examples of the role that UN treaty bodies can play in monitoring these violations, with a focus on South-East Asia. We have also presented a typology of human rights violations associated with LSLAs. In the fourth part, we presented Laos as a case study.

We conclude that three common threads can be extracted from this assessment. The first concern relates to the actual or potential human rights implications of the internal displacement and forced evictions caused by LSLAS, which often lead to drastic changes in livelihood opportunities. The second thread involves the impact of LSLAS on the procedural rights of indigenous peoples, in particular their right to give, or to withhold, their free, prior, and informed consent to policies and activities that directly affect their land, territory and livelihoods. The third recurrent theme is the disproportionately negative effect that LSLAs have on individuals and groups who are vulnerable to discrimination and marginalisation, including women, children, indigenous peoples, rural communities, and small-scale farmers.

Taking a step back, we can conclude that human rights are well recognised in international law and that national laws seem to be adequate in many countries, including in Cambodia and Laos. These rights and laws represent a good basis from which to evaluate the impacts of LSLAs. But these human rights instruments and national laws are poorly implemented in the ground, or not implemented in favour of local communities (see also Cismas and Paramita in this volume). And despite a constructive role played by UN monitoring mechanisms, which certainly offer one of the few avenues that exist for denouncing human rights violations associated with LSLAs, violations continue to be widespread in the countries affected by the phenomenon and evaluated by un experts. 


\section{References}

Alliance for Democracy in Laos (2012) Report of the Alliance for Democracy in Laos about the Human-Rights Situation and the Race Discrimination in Laos, presented to the UN CERD, Hagen (Germany), http://tbinternet.ohchr.org/Treaties/CERD/ Shared\%2oDocuments/LAO/INT_CERD_NGO_LAO_80_9467_E.pdf (accessed on 28 April 2015).

APHR (ASEAN Parliamentarians for Human Rights) (2014) Lao Government's Deceptive Game on Sombath Investigation Must End, press release, 23 September, http://www .aseanmp.org/?p=3101 (accessed on 27 November 2014).

Baird, I. (2011) 'Turning Land into Capital, Turning People into Labour: Primitive Accumulation and the Arrival of Large-Scale Economic Land Concessions in the Lao People's Democratic Republic', New Proposals: Journal of Marxism and Interdisciplinary Inquiry, 5(1), pp. 10-26, http://ojs.library.ubc.ca/index.php/ newproposals/article/view/2264 (accessed on 28 April 2015).

Bassiouni, M.C. and W.A. Schabas (eds.) (2011) New Challenges for the UN Human Rights Machinery. What Future for the UN Treaty Body System and the Human Rights Council Procedures? (Cambridge, Antwerp and Portland: Intersentia).

Biglino, I. and C. Golay (2013) The Optional Protocol to the International Covenant on Economic, Social and Cultural Rights, Geneva Academy In-Brief No. 2 (Geneva: Geneva Academy of International Humanitarian Law and Human Rights), http:// www.geneva-academy.ch/docs/publications/The\%20optional\%2oprotocol\%20 In\%2obrief\%202.pdf (accessed on 28 April 2015).

Borghi, M. and L. Postigione Blommestein (eds.) (2006) The Right to Adequate Food and Access to Justice (Bruxelles and Genève: Bruylant-Schultess).

CEDAW (Committee on the Elimination of Discrimination against Women) (2009)

Concluding Observations of the Committee on the Elimination of Discrimination against Women: Lao People's Democratic Republic, UN doc. CEDAW/C/LAO/Co/7, 14 August.

- (2006) Concluding Comments of the Committee on the Elimination of Discrimination against Women: Cambodia, UN doc. CEDAW/C/KHM/CO/3, 25 January.

CERD (Committee on the Elimination of Racial Discrimination) (2012a) Concluding Observations of the Committee on the Elimination of Racial Discrimination: Lao PDR, UN doc. CERD/C/LAO/CO/16-18, 13 April.

- (2012b) Concluding Observations of the Committee on the Elimination of Racial Discrimination: Viet Nam, un doc. CERD/C/VNM/CO/10-14, 9 March.

(2010) Concluding Observations of the Committee on the Elimination of Racial Discrimination: Cambodia, UN doc. CERD/C/KHM/CO/8-13, 1 April. 
(2007) Concluding Observations of the Committee on the Elimination of Racial

Discrimination: Indonesia, UN doc. CERD/C/IDN/CO/3, 15 August.

CESCR (Committee on Economic, Social and Cultural Rights) (2011) Concluding

Observations of the Committee on the Economic, Social and Cultural Rights: Germany, UN doc. E/C.12/DEU/CO/5, 12 July.

- (2009) Concluding Observations of the Committee on the Economic, Social and Cultural Rights: Cambodia, uN doc. E/C.12/KHM/co/1,12 June.

- (1999) General Comment 12: The Right to Adequate Food (art. 11), UN doc. E/C.12/1999/5, 12 May.

Clays, P. and G. Vanloqueren (2013) 'The Minimum Human Rights Principles Applicable to Large-Scale Land Acquisitions or Leases', Globalizations, 10(1), pp. 193-198, DoI: 10.1080/14747731.2013.760940.

Cotula, L. (2012) "Land Grabbing” in the Shadow of the Law: Legal Frameworks Regulating the Global Land Rush', in Rayfuse, R. and N. Weisfelt (eds.) The Challenge of Food Security. International Policy and Regulatory Frameworks (Cheltenham and Northampton: Edward Elgar) pp. 206-228.

- (ed.) (2009) The Right to Food and Access to Natural Resources. Using Human Rights Arguments and Mechanisms to Improve Resource Access for the Rural Poor (Rome: Food and Agriculture Organization), http://pubs.iied.org/pdfs/Go3o65.pdf (accessed on 28 April 2015).

CRC (Committee on the Rights of the Child) (2011) Concluding Observations: Cambodia, UN doc. CRC/C/KHM/CO/2, 20 June.

De Schutter, O. (2011a) 'How not to Think of Land-Grabbing: Three Critiques of LargeScale Investments in Farmland', The Journal of Peasant Studies, 38(2), pp. 249-279, DOI: 10.1080/03066150.2011.559008.

_ (2011b) 'The Green Rush: The Global Race for Farmland and the Rights of Land Users', Harvard International Law Journal, 52(2), pp. 504-559.

Friis, C. (2013) Land, Livelihoods and Access to Resources in Laos PDR-Large-Scale Land Acquisitions in a Dynamic Context of Agrarian Transformation, unpublished Master's thesis (Copenhagen: Faculty of Science, University of Copenhagen), http:// www.snis.ch/system/files/master_thesis_cecilie_friis_complete_o.pdf (accessed on 28 April 2015).

GDG (Gender and Development Group) (2008) Implementation of the CEDAW Convention. List of Key Issues to be Submitted to the CEDAW Committee, CEDAW presession November 2008, http://www2.ohchr.org/english/bodies/cedaw/docs/ngos/ GDG_Laos_44.pdf (accessed on 28 April 2015).

Gironde, C., C. Golay, P. Messerli, A. Peeters and O. Schönweger (2014) (with the contributions of I. Biglino, I. Cismas, C. Friis, P. Paramita, G. Senties Portilla and S. Seng) Large-Scale Land Acquisitions in Southeast Asia: Rural Transformations between Global Agendas and Peoples' Right to Food', Working Paper (Geneva: Swiss 
Network for International Studies), http://www.snis.ch/system/files/gironde_ working_paper_lsla_southeast_asia_17.08.2014_o.pdf (accessed on 28 May 2015).

Golay, C. (2009) The Right to Food and Access to Justice: Examples at the National, Regional and International Levels (Rome: Food and Agriculture Organization).

Golay, C. and I. Biglino (2013) 'Human Rights Responses to Land Grabbing: A Right to Food Perspective', Third World Quarterly, 34(9), pp. 1630-1650, DoI: 10.1080/01436597.2013.843853.

Golay, C., C. Mahon and I. Cismas (2011) 'The Impact of the UN Special Procedures on the Development and Implementation of Economic, Social and Cultural Rights', The International Journal of Human Rights, 15(2), pp. 299-318, DOI: 10.1080/13642987.2011.537472.

Golay, C. and M. Özden (2009) The Right of Peoples to Self-Determination (Geneva: CETIM).

Human Rights Committee (2009) Ángela Poma Poma v. Peru, Comm. No. 1457/2006, Views of 27 March, UN doc. CCPR/C/95/D/1457/2006.

- (2000) Apirana Mahuika et al. v. New Zealand, Comm. No. 547/1993, Views of 27 October, un doc. CCPR/C/70/D/541/1993.

IN D I G E NOUS (International Network for Diplomacy Indigenous Governance Engaging in Nonviolence Organizing for Understanding \& Self-Determination) (2012) Shadow Report Regarding the Periodic Reports of Laos under the UN Convention on the Elimination on the Elimination of All Forms of Racial Discrimination, for consideration at the 8oth Session of the United Nations CERD, 28-29 February, http:// tbinternet.ohchr.org/Treaties/CERD/Shared\%2oDocuments/LAO/INT_CERD_ NGO_LAO_80_9469_E.doc (accessed on 28 April 2015).

Keller, H. and G. Ulfstein (eds.) (2012) UN Human Rights Treaty Bodies: Law and Legitimacy (Cambridge: Cambridge University Press).

Künnemann, R. and S. Monsalve Suárez (2013) 'International Human Rights and Governing Land Grabbing: A View from Global Civil Society', Globalizations, 10(1), pp. 123-139, DOI: 10.1080/14747731.2013.760933.

Monsalve Suárez, S. (2013) 'The Human Rights Framework in Contemporary Agrarian Struggles', Journal of Peasant Studies, 40(1), pp. 239-290, DOI: 10.1080/03066150.2011.652950.

Narula, S. (2013) 'The Global Land Rush: Markets, Rights, and the Politics of Food', Standford Journal of International Law, 49(1), pp. 101-175, http://ssrn.com/ abstract $=2294521$.

Nifosi, I. (2005) The UN Special Procedures in the Field of Human Rights (Antwerp and Oxford: Intersentia).

Piccone, T. (2012) Catalysts for Change: How the UN's Independent Experts Promote Human Rights (Washington: Brookings Institution Press). 
Radio Free Asia (2012) 'NGO Director Expelled', press release, 7 December, http://www .rfa.org/english/news/laos/expulsion-12072012153813.html (accessed on 27 November 2014).

Robinson, M. (2003) 'Making Human Rights Matter: Eleanor Roosevelt's Time Has Come', Harvard Human Rights Journal, 16, pp. 1-11.

Senties Portilla, G. (2012) Land Concessions in Lao PDR: Transforming Rural Livelihoods and Aspirations, unpublished preliminary thesis dissertation (Geneva: Graduate Institute of International and Development Studies).

Special Rapporteur on Extreme Poverty (2012) Report of the Special Rapporteur on Extreme Poverty and Human Rights, Magdalena Sepulveda Carmona, UN doc. A/67/278, 9 August.

Special Rapporteur on the Right to Food (2011) Mission to Madagascar, Addendum to the Report of the Special Rapporteur on the right to food, Olivier De Schutter, UN doc. A/HRC/19/59/Add.4, 26 December.

- (2009) Large-Scale Land Acquisitions and Leases: A Set of Minimum Principles and Measures to Address the Human Rights Challenge, Annex to the Report of the Special Rapporteur on the right to food, Olivier De Schutter, UN doc. A/HRC/13/33/ Add.2, 28 December.

Subedi, S., S. Wheatley, A. Mulherjee and S. Ngane (2011) 'The Role of the Special Rapporteurs of the United Nations Human Rights Council in the Development and Promotion of International Human Rights Norms', The International Journal of Human Rights, 15(2), pp. 155-161, DOI: 10.1080/13642987.2011.537463.

UNPO (Unrepresented Nations and Peoples Organization) (2012) Parallel Report Presented by Unrepresented Nations and Peoples Organization, Alternative Report submitted to the UN Committee on the Elimination of Racial Discrimination at the 8oth Session during the consideration of the 16th-18th Periodic Reports of Laos (UNPO: The Hague).

Vandehole, W. (2004) The Procedures Before the UN Human Rights Bodies: Divergence or Convergence? (Antwerp and Oxford: Intersentia). 